\section{Eighty Years of Observations on the Adjusted Monetary Base: 1918-1997}

\author{
Richard G. Anderson and \\ Robert H. Rasche
}

\footnotetext{
number of recent trends in empirical

A macroeconomic research-embedding long-run relationships in models via cointegration, modeling the correlation between seasonal cycles and business cycles, building endogenous growth models, and the renewed interest of policymakers in inflation targeting-have increased the importance of long time series of macroeconomic data. Many empirical phenomena suggested by this research are likely to occur only at relatively low frequencies, making long series of data essential. Among the more important of such time series are measures of the monetary base, which furnishes a monetary economy's nominal anchor.

Many empirical analyses of monetary policy assume that the stance of policy is adequately measured by the Federal Open Market Committee's target level for the federal funds rate. But the federal funds rate, or any other financial market interest rate or asset price, is not suitable as a measure of the stance of monetary policy when it is analyzed without corresponding quantity data. Prior to 1964, free reserves, not the federal funds rate, was the Federal Reserve's preferred indicator and frequent policy target (Brunner and Meltzer, 1964). More generally, models of stabilization policy with nonzero correlations among contemporaneous shocks suggest that both interest rates and monetary aggregates should
}

appear in policy feedback rules (Poole, 1970; Friedman, 1990). Further, policies focused solely on interest rates may leave the economy's price level indeterminate, at least in the classes of models most useful for policy analysis (McCallum, 1986, 1997). Finally, as the outside money in a monetary economy, the monetary base furnishes the economy's nominal anchor (Patinkin, 1961; McCallum, 1997).

Previously published data on the adjusted monetary base begin in 1935, seasonally unadjusted, and in 1950, seasonally adjusted. In this analysis, we introduce new data for 1918 through 1935, and combine these data with the later-dated, published series.

\section{THE MONETARY BASE}

An economy's monetary base consists of those liabilities of the monetary authorities that are used as media of exchange by the nonbank public (households and firms other than depository institutions), and those liabilities that are used by depository institutions to settle interbank payments (Balbach and Burger, 1976). In the United States monetary system, the monetary authorities are the U.S. Treasury Department and the Federal Reserve System.

Previous studies of the St. Louis adjusted monetary base have examined data that begin in August 1935 (Andersen and Jordan, 1968; Tatom, 1980; Anderson and Rasche, 1996a). For these dates, the monetary base is equal to the sum of currency in circulation outside the Treasury and the Federal Reserve, plus the deposits of depository institutions at Federal Reserve Banks.

For dates before August 1935, the bestknown measure of the monetary base is the high-powered money series of F riedman and Schwartz (1963), pp. 799-808. The measure introduced in this article differs from theirs in several respects. Our data are from Banking and M onetary Statistics 1914-1941, Table 101, pp. 369-71, and begin August, $1917 .{ }^{1}$

\footnotetext{
1 These data, labeled "Money in Circulation" in Banking and Monetary Statistics, include gold coin in circulation prior to February 1934.
} 


\section{Currency in Circulation}

The Banking and M onetary Statistics data measure currency in circulation as the monthly average of daily levels. Friedman and Schwartz's data measure currency as of the last day of the month. Our data are not seasonally adjusted, while Friedman and Schwartz's data are seasonally adjusted. By using such seasonally unadjusted data, we can create our adjusted monetary base as a chain index and, thereafter, examine separately its seasonality. We also exclude Friedman and Schwartz's adjustment for $\$ 287$ million of missing gold coin; see Friedman and Schwartz (1963), pp. 46364 , footnote 45 .

\section{Deposits of Banks at the Federal Reserve}

Similar to currency, the Banking and M onetary Statistics data measure the deposits held by banks at Federal Reserve Banks as the monthly average of daily balances. Friedman and Schwartz's data measure deposits as of the end of the month or the last Wednesday of the month. We also do not include an adjustment for Federal Reserve float. Friedman and Schwartz (1963, p. 748) include a measure of float that is constructed primarily from end-of-month figures, with some months interpolated from less frequent observations. In any case, the inclusion or exclusion of float makes little difference. Float usually is small. At the end of January 1936, for example, float was only about $\$ 2$ million (Annual Report of the Board of Governors of the Federal Reserve System for 1936, June 1937, p. 74). We also omit clearing balances held by nonmember banks at the Federal Reserve Banks, due to the paucity of data. Friedman and Schwartz (1963, p. 748) create a time series for these balances by linear interpolation between the only published values: last day of the year figures in the Federal Reserve Board's Annual Report. These nonmember clearing balances are small, relative to total member bank deposits: $\$ 91$

${ }^{2}$ A broad cross-country study illustrating the importance of such adjustments is McCallum and Hargraves (1995). million and \$123 million on December 31, 1935 and 1936, respectively (Annual Report of the Board of G overnors of the Federal Reserve System for 1935, p. 83, and Annual
Report of the Board of G overnors of the F ederal Reserve System for 1936, p. 73). M ember bank deposits were $\$ 5.587$ and $\$ 6.606$ billion on these dates (Banking and M onetary Statistics, p. 332). These data also are not seasonally adjusted, while Friedman and Schwartz's published data are seasonally adjusted.

\section{THE RAM ADJ USTMENT}

Changes in statutory reserve requirements often cause depository institutions to change the amount of base money that they hold. These changes have no implication for the stance of monetary policy and should be removed from the adjusted monetary base. ${ }^{2}$ One such adjustment- the reserve adjustment magnitude, or RAM - was introduced by Karl Brunner, and has been extended by Burger and Rasche (1977) and Anderson and Rasche (1996b). The RAM adjustment measures the amount by which changes in statutory reserve requirements- relative to those in effect during a specific base periodhave changed the quantity of base money held by depository institutions.

Measuring RAM precisely requires a model of depository institutions' asset management that includes an explicit role for statutory requirements. Such a model is beyond the scope of this paper. The underlying concept, however, may be illustrated simply if we assume that all base money held by depository institutions is el igible to satisfy statutory reserve requirements. (In the United States, vault cash could not be used to satisfy reserve requirements between 1917 and 1959.) In this case, the amount of base money held by a depository institution, when statutory reserve requirements are relatively high, will be determined largely by the amount of its required reserves. Conversely, when statutory requirements are relatively low, the amount held will be largely determined by the depository's business needs, such as converting customer deposits into currency, making interbank wire transfers, and settling interbank check collection debits.

Let us suppose that a depository institution's demand function for base money may be written as MBD $(d, r r)$, where $d$ is the institution's deposit liabilities and $r r$ is 


\section{RESERVE REQUIREMENTS IN THE UNITED STATES SINCE 1914}

When the Federal Reserve System opened for business in May 1914, member banks became subject to statutory reserve requirements set by the Federal Reserve. (Banks that held federal, or national, charters were required by law to be members of the Federal Reserve System. M embership was optional for state-chartered banks.) In 1980, implementation of the Monetary Control Act made all depository institutions subject to the requirements set by the Federal Reserve.

The Federal Reserve's statutory reserve requirements specify three items: the type and amount of deposits subject to requirements, the reserve requirement ratio applicable to these deposits, and the bank's assets that are eligible to satisfy the requirements. For examples of how changes in these regulations have affected measurement of the adjusted monetary base, see Burger and Rasche (1977) and Anderson and Rasche (1996b).

Prior to 1972 , reserve requirement ratios differed across three separate categories of member banks: central reserve city banks, reserve city banks, and country banks. Originally, there were three central reserve cities: N ew York, Chicago, and St. Louis. As discussed in the text of this article, St. Louis was reclassified as a reserve city in 1922. In 1972, these categories were eliminated and a new system of requirements initiated. In the new system, reserve requirement ratios vary with the amount of deposits held by a bank, not by its location.

Depository institutions satisfy their requirements today by holding cash-invault and deposits at Federal Reserve Banks. Between August 1917 and November 1959, however, only deposits at Federal Reserve Banks could be used to satisfy requirements; vault cash was not eligible. The eligibility of vault cash was phased in between December 1959 and December 1960. Details are available in Banking and M onetary Statistics 19141941, p. 401, and Annual Report of the Board of Governors of the Federal Reserve System for 1972, pp. 45-46.

Prior to the 1980, depository institutions that were not members of the Federal Reserve were subject to reserve requirements set by state regulators. Because most such requirements could be satisfied by holding interest-bearing liquid assets and/or deposits in banks, as well as vault cash, it seems unlikely that these requirements significantly affected the quantity of base money demanded by these institutions. Hence, these requirements do not enter into our measure of RAM . the statutory reserve requirement ratio. If statutory reserve requirements are, at the margin, the binding constraint that determines the amount of base money held by the depository, then

$$
\frac{\partial M B^{D}(d, r r)}{\partial r r}>0 \text {. }
$$

If the depository's business needs, rather than statutory requirements, are the binding constraint, then

$$
\frac{\partial M B^{D}(d, r r)}{\partial r r}=0 .
$$

To measure RAM, we must be able to estimate (or infer) the sign of the derivative

$$
\frac{\partial M B^{D}(d, r r)}{\partial r r}
$$

at all dates in our sample, for each set of statutory reserve requirements.

To be more specific, let us denote a depository institution's level of required 


\section{WHY DOES RAM BEGIN IN 1917?}

The RAM adjustment in this article begins in August 1917 for two reasons. First, the purpose of our analysis is to extend previously published monthly data to earlier dates, for use in subsequent econometric analysis. The earliest available month-average data on the daily level of the monetary base begin in August, 1917 (Banking and M onetary Statistics 1914-1941, pp. 369-71), although annual data are available for earlier dates.

Second, the data required to measure RAM are not available for dates prior to August 1917. The structure of the statutory reserve requirements that applied to Federal Reserve System member banks changed sharply on June 21, 1917. Prior to this date, member banks were required to satisfy a minimum of one-third of their required reserves with vault cash, and could at their discretion satisfy up to two-thirds with vault cash; separate minimum ratios were specified for satisfying requirements in vault cash and in Federal Reserve Bank deposits. On June 21 , vault cash became ineligible to satisfy required reserves, and reserve requirement ratios for net demand deposits were reduced by 5 percentage points- to 13,10 and 7 percent from 18,15 and 12 percent for central reserve city, reserve city, and country banks, respectively. According to Federal Reserve Board staff, the changes were intended to "centralize" the holding of reserve balances (Annual Report of the Board of Governors of the Federal Reserve System for 1935, pp. 17-18). At the time, it was expected that the changes would have little effect on the overall demand for base money. If the decrease in a bank's required reserves was approximately equal to the amount of its vault cash, and if the bank's demand for vault cash was determined primarily by dayto-day operations rather than by statutory requirements, then the demand for base money might change little. Interestingly, this argument is similar to one made by the Bundesbank in 1995 when it al so reduced reserve requirement ratios and made vault cash ineligible to satisfy requirements ( $M$ onthly Report, Deutsche Bundesbank, July 1995, pp. 25-26).
${ }^{3}$ In the notation of the text, the vertical bar indicates that the derivative is evaluated at the values of $d$ and $r r$ shown at the bottom end of the bar. reserves during period $t$, as $R R\left(d_{t}, r_{t}\right)$. Also, let us denote as $R R\left(d_{t}, r r_{0}\right)$ what the same institution's level of required reserves would have been during period $t$, if the statutory reserve requirements of a base period, denoted as period 0 , had been in effect. (For all cases, we assume that sufficient data exist so as to permit calculation of the quantity $\operatorname{RR}\left(d_{t}, r r_{0}\right)$.) Then, consider four cases:

Case 1: If $r r_{0}=r r_{t}$, that is, the reserve requirement ratio has not changed, then $\mathrm{RAM}=0$.

Case 2: If:

$$
\left.\frac{\partial M B^{D}(d, r r)}{\partial r r}\right|_{\substack{d=d_{0} \\ r r=r r_{0}}}=0,
$$

and

$$
\left.\frac{\partial M B^{D}(d, r r)}{\partial r r}\right|_{\substack{d=d_{t} \\ r r=r_{t}}}=0,
$$

that is, if the business needs of the bank were the binding constraint in both the base period 0 and period $t$, then RAM $=0 .{ }^{3}$

Case 3: If both:

$$
\left.\frac{\partial M B^{D}(d, r r)}{\partial r r}\right|_{\substack{d=d_{0} \\ r r=r r_{0}}}>0
$$


and

$$
\left.\frac{\partial M B^{D}(d, r r)}{\partial r r}\right|_{\substack{d=d_{t} \\ r r=r r_{t}}}>0,
$$

that is, if the statutory requirements were the binding constraint on the bank in both the base period 0 and period $t$, then the RAM adjustment for period $t$ (conditional on the choice of period 0 as the base period) is:

$$
\operatorname{RAM}_{t}=R R\left(d_{t}, r r_{0}\right)-R R\left(d_{t}, r r_{t}\right) \text {. }
$$

Case 4: If:

$$
\left.\frac{\partial M B^{D}(d, r r)}{\partial r r}\right|_{\substack{d=d_{0} \\ r r=r r_{0}}}>0,
$$

but

$$
\left.\frac{\partial M B^{D}(d, r r)}{\partial r r}\right|_{\substack{d=d_{t} \\ r r=r r_{t}}}=0,
$$

that is, if the statutory requirements were binding in the base period but not in period $t$, then to measure RAM we must find the smallest reserve requirement ratio, say $r r^{*}$, for which

$$
\left.\frac{\partial M B^{D}(d, r r)}{\partial r r}\right|_{\substack{d=d_{t} \\ r r=r^{*}}}>0 .
$$

Then, $R A M_{t}=R R\left(d_{t}, r r_{0}\right)-R R\left(d_{t}, r r^{*}\right)$. An empirical criterion for measuring RAM in this case was developed by Anderson and Rasche (1996b), based on statistical analysis of a large panel data set.

The above analysis assumes that the only change in statutory reserve requirements between periods 0 and $t$ is a change in the reserve requirement ratio, $\mathrm{rr}$. It also assumes that the data exist to calculate the counterfactual level of required reserves, $\operatorname{RR}\left(d_{t}, r r_{0}\right)$. But these assumptions may not be satisfied if other aspects of the reserve requirement system - such as the categories of deposits subject to requirements-change. Then, a lack of data may make it impossible to calculate $R R\left(d_{t}, r r_{0}\right)$ and, hence, the value of
RAM. One example of such a change is the shift in 1972 from a structure of reserve requirements based on location (with central reserve city, reserve city, and country categories), to a structure based on the amount of deposits held by a bank. A second example is the Monetary Control Act's extension in 1980 of statutory reserve requirements to nonmember depository institutions, which had not been subject to Federal Reserve requirements previously. In such cases, a new base period must be selected, and a new RAM series begun.

For long time series of data, multiple changes in statutory reserve requirements might require several separate segments of RAM. N evertheless, within each such segment, the adjusted monetary base is equal to the sum of the monetary base and the appropriate RAM. As long as the resulting multiple segments overlap by at least one observation at each break point, they may be chained together to form a single measure of the adjusted monetary base. A procedure for doing so was suggested by Tatom (1980). His procedure is applied as follows. Beginning with the earliest-dated observation, move forward in time to the first overlapping break point in the data. At this date, calculate the ratio of the first observation in the next segment of data to the final observation in the prior segment, then multiply all earlier-dated data by this ratio. Repeat this procedure for all segments and all break points. An advantage of this procedure is that it preserves the growth rates of the series, and allows the final time series to be interpreted as a chained indexnumber measure of the Federal Reserve's policy actions.

Tatom (1980) calculated segments of RAM for three reserve-requirement base periods:

- RAM (1935) for August 1935 through December 1972 using the reserve requirement structure of August 1935 as the base period;

- RAM (1972) for December 1972 through January 1975, using December 1972 as the base period; and 
- RAM (1975) for January 1975 through October 1980 using January 1975 as the base period.

An additional segment, RAM (1991) for dates beginning October 1980 was constructed by Anderson and Rasche (1996b), using the reserve requirement structure of January 1991 as the base period. These RAM adjustments permit us to construct a measure of the adjusted monetary base that begins in August 1935 and is chained in December 1972, December 1975, and October 1980. This measure has been published by the Federal Reserve Bank of St. Louis since early 1996 (Anderson and Rasche, 1996a).

To measure the adjusted monetary base during the earlier period between 1917 and 1935, we must measure the effects of three changes in statutory reserve requirements:

1) St. Louis was reclassified, as of July 1922, from a central reserve city to a reserve city.

2) The reserve requirement ratio applicable to U.S. government deposits was increased, as of August 1935, from zero to the same ratio as applicable to other demand deposits.

3) In August 1935, the method of calculating the amount of net demand deposits subject to reserve requirements was changed.

To adjust the monetary base for these events, we introduce an additional, fifth RAM, denoted RAM (1922), that spans the period from August 1917 to August 1935, and uses July 1922 as its base period. Its calculation is explained below.

In addition to these three changes, there were a number of changes in reserve requirements that we do not consider; see Banking and M onetary Statistics 1914-1941, p. 401. The Federal Reserve Act gave the Board the flexibility to reclassify banks in the outlying areas of larger cities and in annexed areas as country banks. Most changes consisted of reclassifying banks, branches, and cities among the categories of central reserve city, reserve city, and country. The data necessary to estimate the effect of these changes on the quantity of base money demanded are sparse. Further, because these changes affected relatively smaller banks, the aggregate effects likely are much smaller than those from the reclassification of St. Louis. We do not consider any of these changes in this analysis.

- Reclassification of St. Louis as a Reserve City: The structure of reserve requirements in effect as of 1914 designated three central reserve cities: N ew York City, Chicago, and St. Louis. Based on a petition by its bankers, St. Louis was reclassified by the F ederal Reserve Board as of July 1, 1922, to be a reserve city, thereby reducing reserve requirements on the banks in St. Louis. Measuring RAM (1922) for dates prior to July 1922 requires deposit data for the affected banks. Unfortunately, as far as we have been able to determine, the Federal Reserve retains neither a list of these banks nor data on their deposits. Hence, our RAM for this period is based on published deposit data for the weekly reporting banks in St. Louis. (These data begin December 1917.)

We believe this proxy is satisfactory for several reasons. First, evidence suggests that in St. Louis the central reserve city and weekly reporting banks were the same banks. Data for weekly reporting banks as published in the Federal Reserve Bulletin from December 1917 through October 18, 1918, had separate classifications for central reserve city and reserve city banks. For the week of October 18, 1918, the Bulletin table shows 14 reporting central reserve city banks in St. Louis. Beginning with the week of October 25, 1918, the title on the table in the Bulletin was changed to "Reserve City Banks." There remained 14 reporting banks for that week in the city of St. Louis, however. (The number of reporting banks in the other central reserve cities, New York and Chicago, also did not change.) Our conclusion - that all central reserve city banks were weekly reporting banks- is further supported by call report data. The deposit and asset totals on published call 
reports for central reserve city banks in N ew York City and Chicago are approximately the same as the totals for the weekly reporting banks in these cities. Finally, bank directories of the period provide additional, corroborative evidence. From January 10, 1919, through July 3,1919 , the Bulletin tables show 15 weekly reporting banks in St. Louis. The Rand M cN ally Bank Directory for January 1919, identifies 16 member banks within the city of St. Louis. Of these banks, 15 were in or near the downtown core; one bank, the smallest, was on the outskirts of the city. We are confident that the largest 15 banks were both the weekly reporting and central reserve city banks in St. Louis, and hence, that it is accurate to use published data on net demand deposits at weekly reporting banks in St. Louis to measure RAM (1922).

- Reserve Requirements on U.S. Government Deposits: In August 1935, U.S. government deposits became subject to the same statutory reserve requirements as were applied to private demand deposits. ${ }^{4}$ Government deposits previously had become exempt from reserve requirements in 1917 due to a provision in the Liberty Bond Act. Because demand deposits at central reserve city, reserve city, and country banks were subject to different reserve requirement ratios-13, 10, and 7 percent, respectively - to accurately measure the impact of this change on required reserves would require individual-bank data, which are not available. Below, we use an estimate published by the Federal Reserve Board in its Annual Report for 1935.

- Rules for the Calculation of Required Reserves: The change in the definition of net demand deposits subject to reserve requirements, as of August 1935, is described in Banking and Monetary Statistics 19141941, pp. 65-66:

[Prior to the Banking Act of 1935] net demand deposits of a member bank ... were made up of ( 1 ) the gross amount of all demand deposits except those due to other banks, and (2) the net excess (if any) of demand deposits due to other banks over demand balances due from other domestic banks and cash items in process of collection. From
April 24, 1917, to August 23, 1935 ... United States Government deposits were exempt by law from all reserve requirements and were, therefore, excluded from net demand deposits.

The Banking Act of 1935 brought about a fundamental change in the definition of net demand deposits: it prescribed that reserves be carried against United States Government deposits, and permitted allowable deductions to be offset against total demand deposits instead of against demand deposits due to banks. Net demand deposits thus were defined as the excess of all demand deposits, including deposits due to banks and the U nited States Government, over demand balances due from other domestic banks (except Federal Reserve Banks, foreign banks or branches thereof, foreign branches of domestic banks, and private banks) and cash items in process of collection.

The amount by which this redefinition changed the required reserves of an individual member bank depended on that bank's size and mixture of deposits. The aggregate change in required reserves cannot be calculated from aggregate data. ${ }^{5}$

The measurement of RAM (1922)

may now be described. First, from December 1917 through June 1922, RAM (1922) measures the difference between the required reserves that St. Louis central reserve city banks would have held if the statutory reserve requirements of July 1922 had been in effect, and their actual required reserves. St. Louis central reserve city banks, from December 1917 through June 1922, faced a 13 percent reserve requirement ratio on net demand deposits; a 10 percent ratio became effective as of July 1, 1922, the base period for RAM (1922). Hence, for $t=$ December 1917 through June 1922, RAM (1922) is:

RAM $(1922)_{\mathrm{t}}=0.10 *($ Net Demand Deposits, St. Louis Weekly Reporting

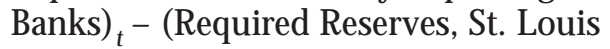
Weekly Reporting Banks) t.

\footnotetext{
${ }^{4}$ Federal Reserve Bulletin, September 1935, p. 618.

5 See Banking and Monetary Statistics 1914- 1941, p. 66, and especially footnote 13.
} 


\section{Table 1}

RAM Adjustment Due to Reclassi cation of St. Louis from a Central Reserve City to a Reserve City, J uly 1, 1922

\begin{tabular}{|c|c|c|c|c|c|c|}
\hline & \multicolumn{6}{|c|}{ (Millions of Dollars) } \\
\hline & Jan. & Feb. & Mar. & Apr. & May & Jun. \\
\hline 1917 & -- &.- &.- &.- & -- & -- \\
\hline 1918 & -5.888 & -5.828 & -5.073 & -5.612 & -5.495 & -5.466 \\
\hline 1919 & -6.100 & -6.075 & -6.092 & -5.979 & -6.023 & -6.054 \\
\hline 1920 & -7.781 & -7.545 & -7.700 & -7.265 & -6.771 & -6.782 \\
\hline 1921 & -6.877 & -6.788 & -6.570 & -6.453 & -6.180 & -5.907 \\
\hline 1922 & -6.474 & -6.636 & -6.523 & -6.567 & -6.564 & -6.527 \\
\hline & Jul. & Aug. & Sept. & oct. & Nov. & Dec. \\
\hline 1917 & -- & $-\cdot$ & -- &.- & -. & -5.687 \\
\hline 1918 & -5.364 & -5.796 & -5.715 & -5.548 & -5.483 & -5.998 \\
\hline 1919 & -6.399 & -6.888 & -6.836 & -6.812 & -7.131 & -7.350 \\
\hline 1920 & -6.773 & -6.761 & -6.619 & -6.387 & -6.344 & -6.523 \\
\hline 1921 & -5.848 & -5.881 & -5.834 & -5.961 & -6.077 & -6.203 \\
\hline 1922 & 0 & 0 & 0 & 0 & 0 & 0 \\
\hline
\end{tabular}

Its values, shown in Table 1, range between $-\$ 7.8$ and $-\$ 5.0$ million. Second, from July 1922 through July 1935, RAM (1922) equals zero. Finally, in August 1935, we set RAM (1922) equal to the reduction in the required reserves of member banks as reported by the Federal Reserve Board, $\$ 35$ million. ${ }^{6}$

The five RAM adjustments used to construct the adjusted monetary base are plotted in Figure 1. In general, the size of a RAM adjustment during any specific period is smaller (larger) than during its base period if statutory reserve requirements are higher (lower) than during the base period. RAM (1935), for example, becomes large and negative during 1937-38 as a result of the Federal Reserve doubling the reserve requirement ratios on member banks. The small size of RAM (1922) relative to later adjustments suggests that minor errors in its measurement are unimportant and that further research to measure the effects of other changes in reserve requirements prior to 1935 would not be worthwhile.

\section{SEASONAL ADJ USTMENT}

Most empirical modeling is done with seasonally adjusted data, despite cautions that such filters may distort dynamic relationships; see for example Wall is (1974) and Harvey and Scott (1994). Seasonal adjustment of relatively long time series, such as the one in this analysis, is troublesome because of structural shifts in the data generating process. If the seasonal process is not separable from other parts of the data generating process-as suggested by Barsky and Miron (1989), Beaulieu, MacKie-M ason, and Miron (1992), and others- then seasonality might diminish or even vanish during periods of unusual economic activity. We identify such a shift during the Great Depression and World War II.

The growth rate and autocorrelation function of the adjusted monetary base, for our full sample and three subperiods, are shown 1935, p.19. 
in Figure 2. As expected, significant seasonal variation is apparent, except perhaps for the period stretching from early 1933 (the year of the third banking panic during the 1930s) through the late 1940s (approximately the end of the Federal Reserve's bond-pegging period). During the latter part of our sample, between 1950 and 1997, seasonal variation appears both more regular (as indicated by the autocorrelation function) and, generally, weaker (as indicated by the growth rates) than in earlier decades.

Our analysis of the seasonal variation in the adjusted monetary base proceeds in two steps. First, we examine the stability of seasonal variation decade-to-decade within the confines of deterministic seasonality. Next, we extend the analysis to allow stochastic seasonality, and summarize seasonal adjustment factors estimated by both the Bureau of the Census X11 and X12-regARIMA programs. ${ }^{7}$ For $X 11$, we use the program included in version 4.31 of the RATS econometrics package. For X12-regARIMA, we use the version for PC DOS dated June 1998, available from the Bureau of the Census at $\varangle$ tp.census.gov $>$. The length of our time series, and the high degree of apparent noise during some periods, suggests that the extensive tests for outliers and sophisticated diagnostics contained in the X12-regARIMA package may be particularly valuable (Findley et. al., 1998).

\section{Tests Based on Deterministic Seasonality}

We begin our investigation of the seasonal properties of the adjusted monetary base by testing the hypothesis that the seasonal pattern differs decade-by-decade. For this test, we assume deterministic seasonality (represented by monthly dummy variables) and interact these variables with a set of decade-specific dummy variables.

The null hypothesis that there are no month/decade interactions over the full sample between 1918 and 1997 is rejected with an F-statistic of $1.78,77$ and 840 degrees of freedom, and a p-value less than 0.001 . $\mathrm{N}$ ext, we test the less restrictive hypothesis that there are no month/decade interactions

\section{Figure 1}

Five Segments of RAM, December 1917December 1997

Millions of Dollars

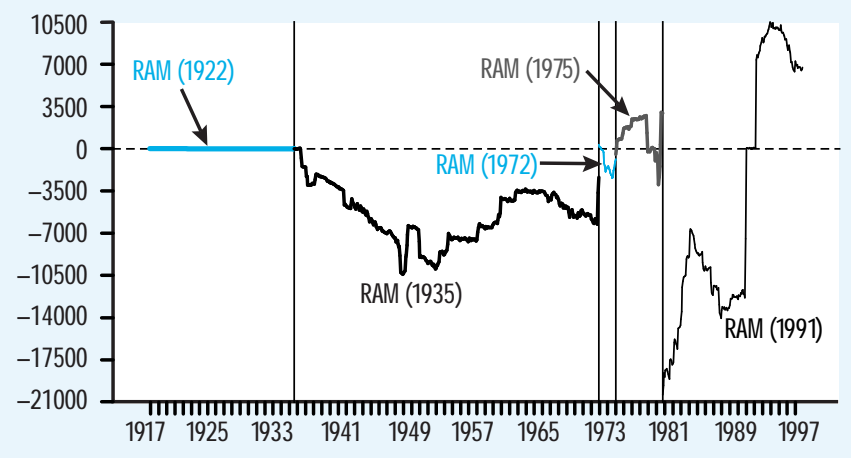

between 1950 and 1997. The hypothesis is not rejected, with an F-statistic of $0.81,44$ and 840 degrees of freedom, and a p-value of 0.80 . Third, we test the significance of the resemblance between the seasonal variation during the 1920s to that from 1950 through 1997. This null hypothesis- that the seasonal patterns are the same- is rejected at the 5 percent level; the F-statistic is 1.60, 66 and 840 degrees of freedom, and a p-value of 0.002 . Finally, we test the null hypothesis that there is no month/decade interaction during the 1930s and 1940s. This hypothesis is rejected, with an F-statistic of 2.58, 22 and 840 degrees of freedom, and a p-value less than 0.001 .

Hence, within the limits of assuming only deterministic seasonality, we conclude that seasonal fluctuations in the adjusted monetary base were:

- reasonably constant between 1950 and 1997;

- weakly similar during 1920-29 and 1950-97;

- different during 1930-49 than during the other decades in our sample.

The statistical conclusions of the previous paragraph are reinforced through the sequence of tier charts in Figures $3 a$ and $3 b$. The eight panels of the figure display the level of the adjusted monetary base, by decade, nor-

\footnotetext{
${ }^{7}$ Deterministic and stochastic seasonality, and the X11 algorithms, are discussed by den Butter and Fase (1991).
} 

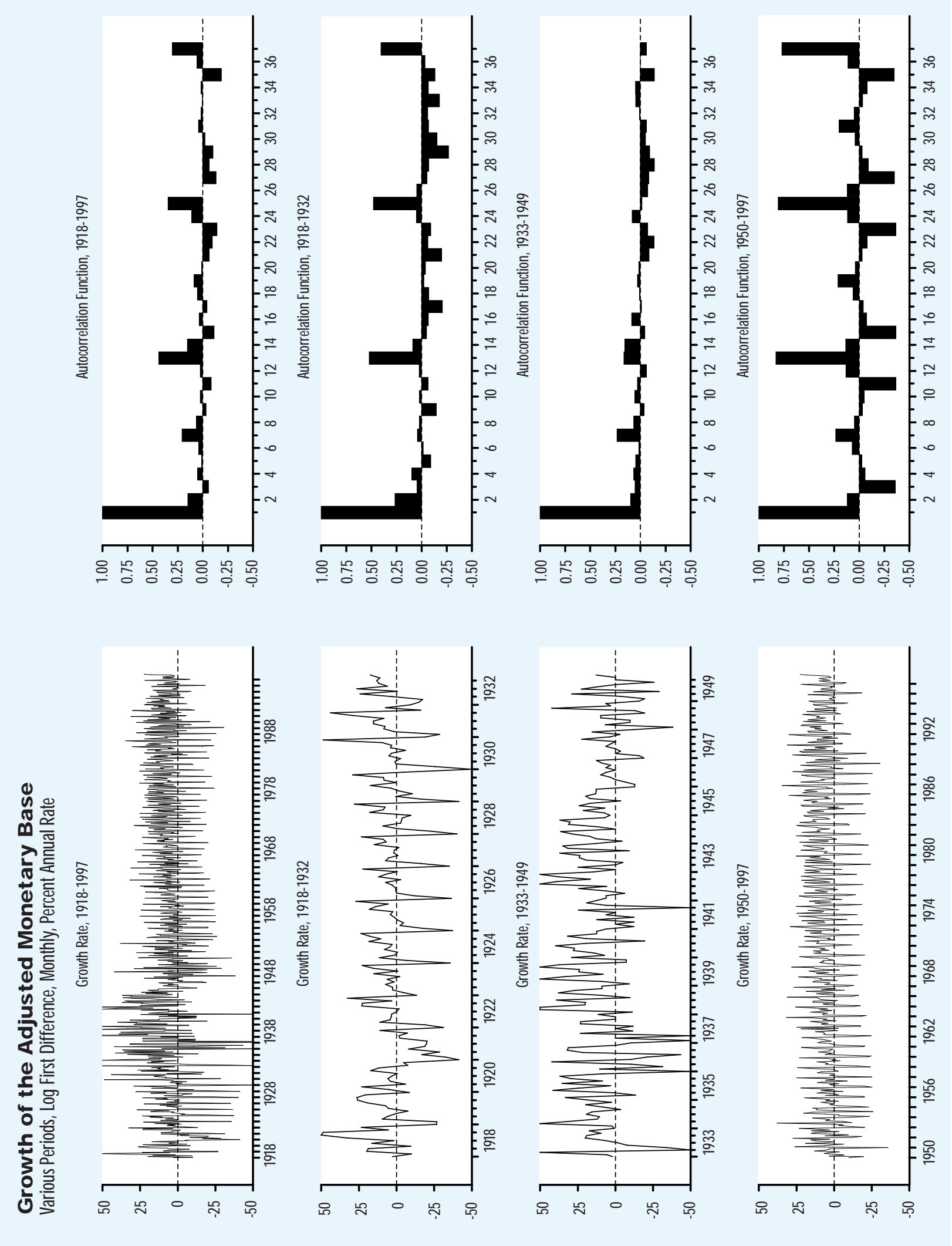


\section{PEVIEW}

JANUARY / FEBRUARY 1999

\section{Figure $3 a$}

Adjusted Monetary Base, NSA

Levels, Normalized to 1.0 in June
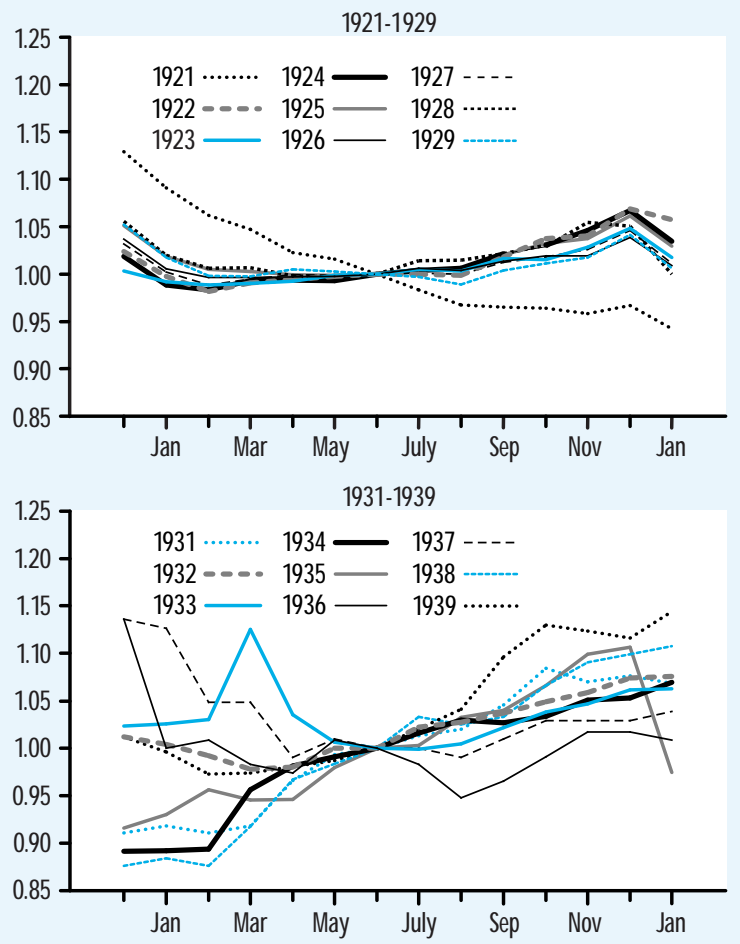

1941-1949

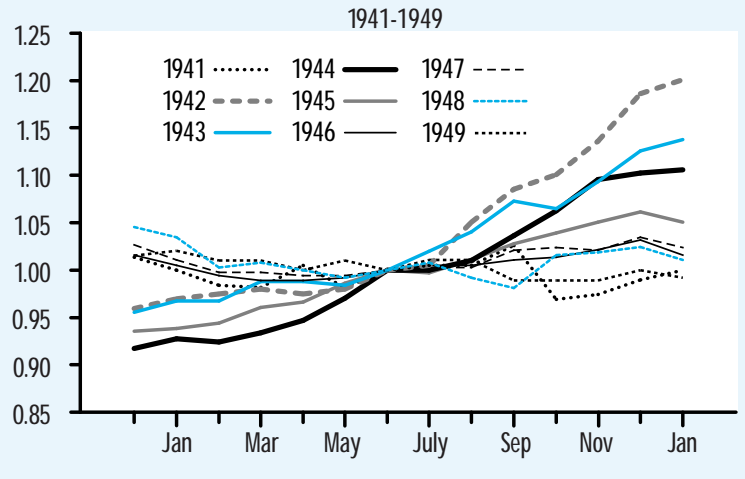

1951-1959

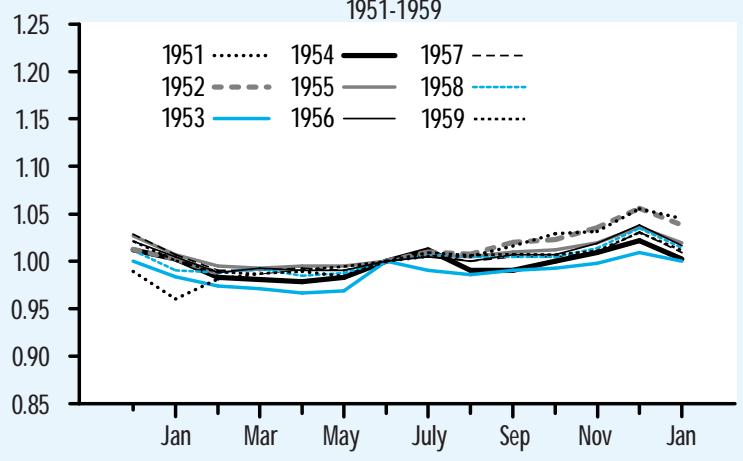

malized to the June level of each year. (Because of software limitations, only nine years of a decade are shown in each panel.) The historically unprecedented sharp drop in the level of the monetary base during 1920 and 1921 is apparent in the first panel. The other years of the decade display a clear, uniform seasonal pattern, with the exception, perhaps, of the second half of 1929. In contrast, little if any regular seasonal variation is apparent during the 1930 s and 1940s, at least through 1945 . The latter years of the 1940s hint at an emerging pattern similar to that observed during the 1920s. A more regular seasonal pattern does emerge during the 1950s, and the pattern tightens during the 1960s, 1970s, and 1980s. The 1990s display more variation, but the same underlying pattern is clear.

The stability of monthly seasonal variation across decades is further explored in Figure 4 through a series of month plots.
In each panel, the growth rates for one month are shown for all years in the sample. Month plots are particularly useful for assessing when an uncertain seasonal pattern settles into a stable pattern, or vice versa. In Figure 4, the decades of the 1930s and 1940s are shaded, and 1950 - the year when our earlier analysis suggests some emerging stabilityis marked. The month plots suggest two conclusions. First, seasonal monthly growth rates tend to stabilize after 1950, and second, there may be significant time variation in the seasonal patterns (stochastic seasonality).

Overall, these results suggest that the adjusted monetary base displays a persistent seasonal pattern that becomes apparent during the 1920s, is interrupted by the Depression and World War II, and reestablishes itself after 1950 (as the Federal Reserve relaxes its pegging of government bond prices). We emphasize that this seasonal data generating process is indeed very 


\section{Figure 3b}

\section{Adjusted Monetary Base, NSA}

Levels, Normalized to 1.0 in June
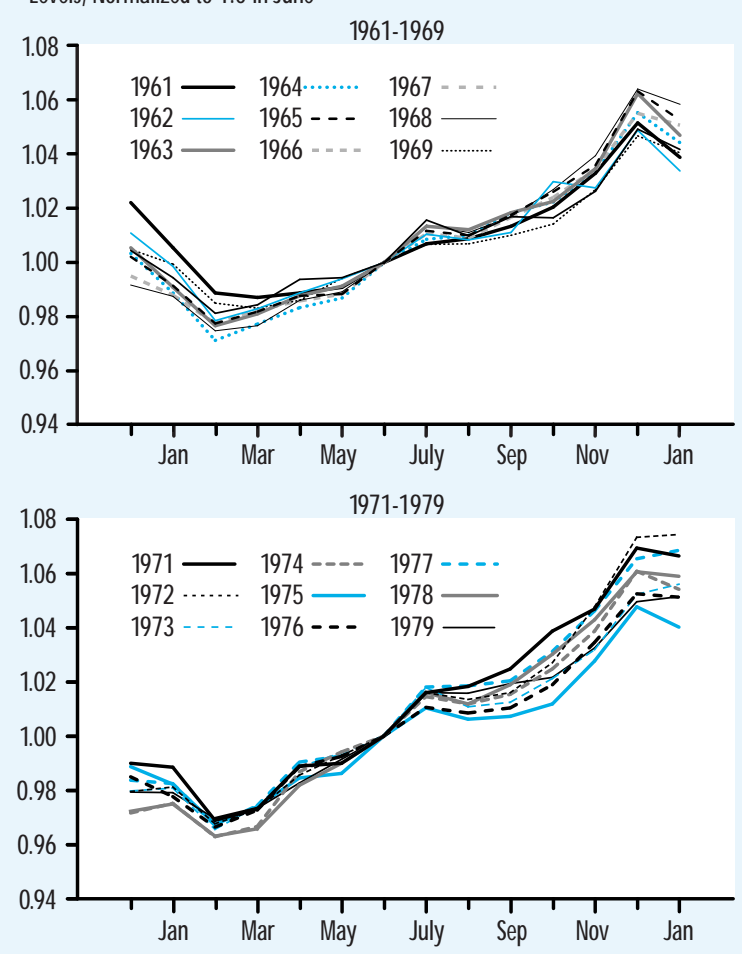

1981-1989

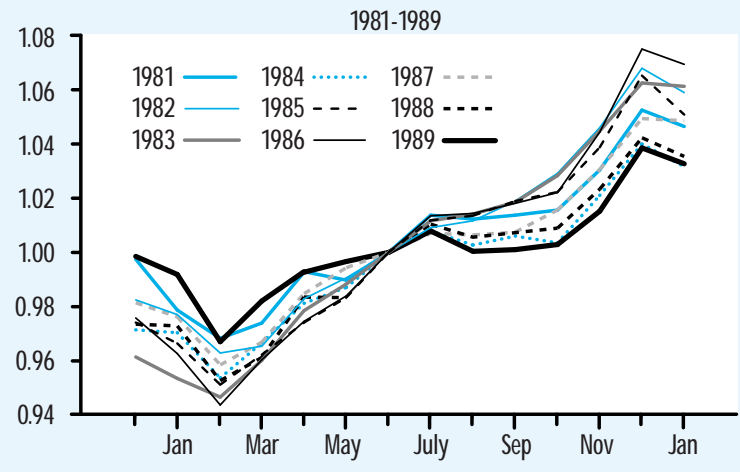

1991-1997

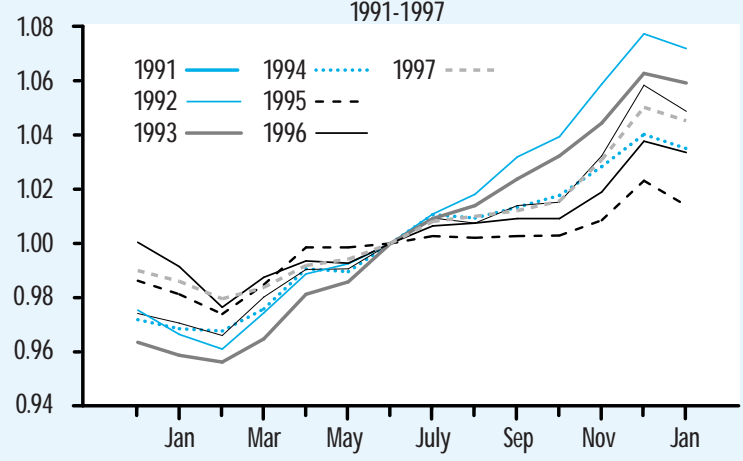

8 den Butter and Fase (1991) describe the algorithm. special. Because base money can neither be created nor destroyed by the private sector of the economy, this seasonal pattern necessarily reflects, in full extent, the Federal Reserve's actions to smooth seasonal fluctuations in the demand for base money and market interest rates.

\section{Tests Based on Stochastic Seasonality}

We next extend our analysis of seasonal variation to allow for time-varying, stochastic seasonality, by use of the Bureau of the Census X 11 and X12-regARIMA seasonal adjustment programs. In this analysis, it is important to appreciate two aspects of the $X 11$ algorithm: outlier replacement and the use of two-sided moving average filters. First, the $X 11$ algorithm searches for outliers during estimation of seasonal adjustment factors, and replaces these data points with more moderate observations. ${ }^{8}$ Outliers are detected by a sequential procedure. First, the X 11 algorithm removes a stochastic (time-varying) trend from the data. N ext, the al gorithm searches, roughly in five-year intervals, for data points more than 1.5 standard deviations from the mean. By default, points between 1.5 and 2.5 standard deviations are replaced with a linear combination of values at 1.5 and 2.5 deviations; points beyond 2.5 standard deviations are replaced with values at 2.5 standard deviations. (These bounds may be changed by the user.)

It is well known that, as a result of this replacement process, the X 11 algorithm might (in some circumstances) produce apparently reasonable seasonal factors even for extremely noisy data. Some recent analysis suggests that this outlier replacement algorithm may be augmented by pre-filtering the series via the introduction of intervention terms in regression models with ARIMA disturbance processes (Findley et. al., 1998). Second, $\mathrm{X} 11$ and $\mathrm{X} 12$ use centered two-sided moving 

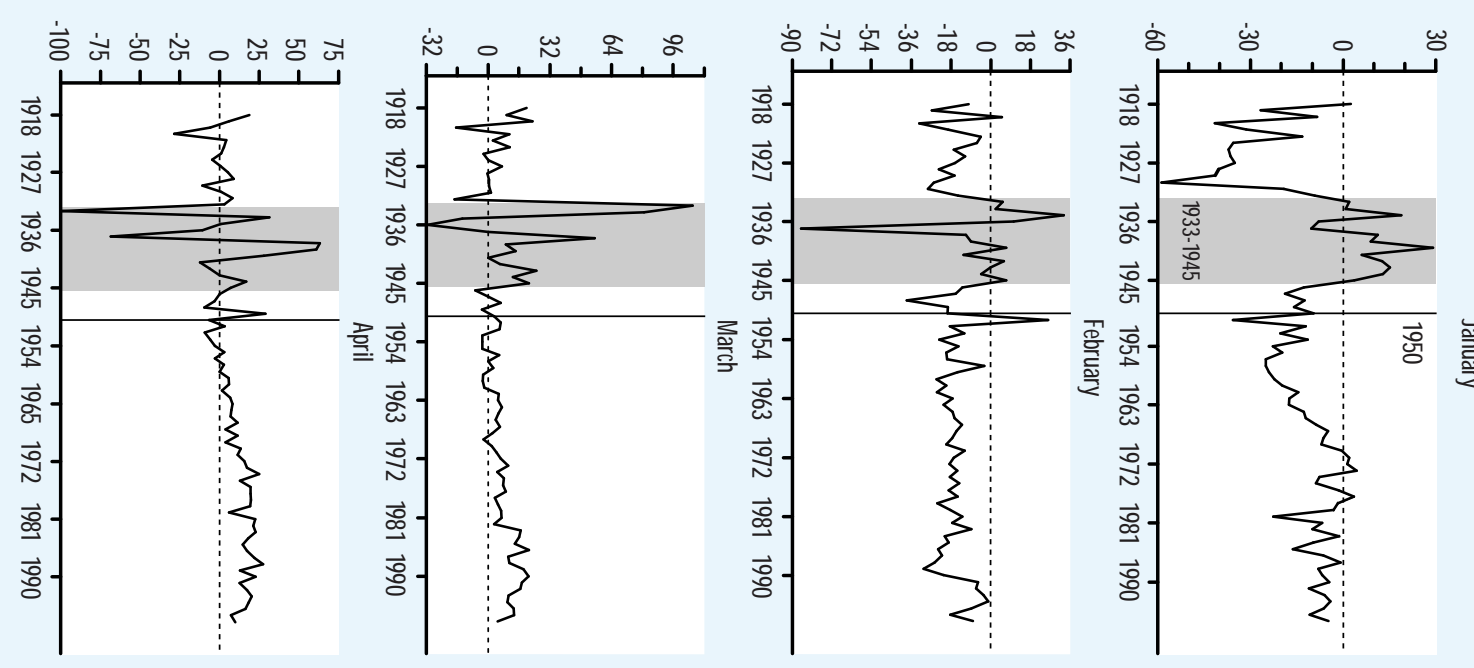

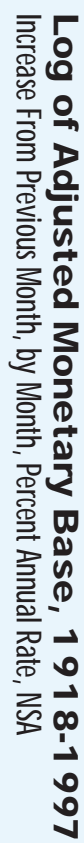
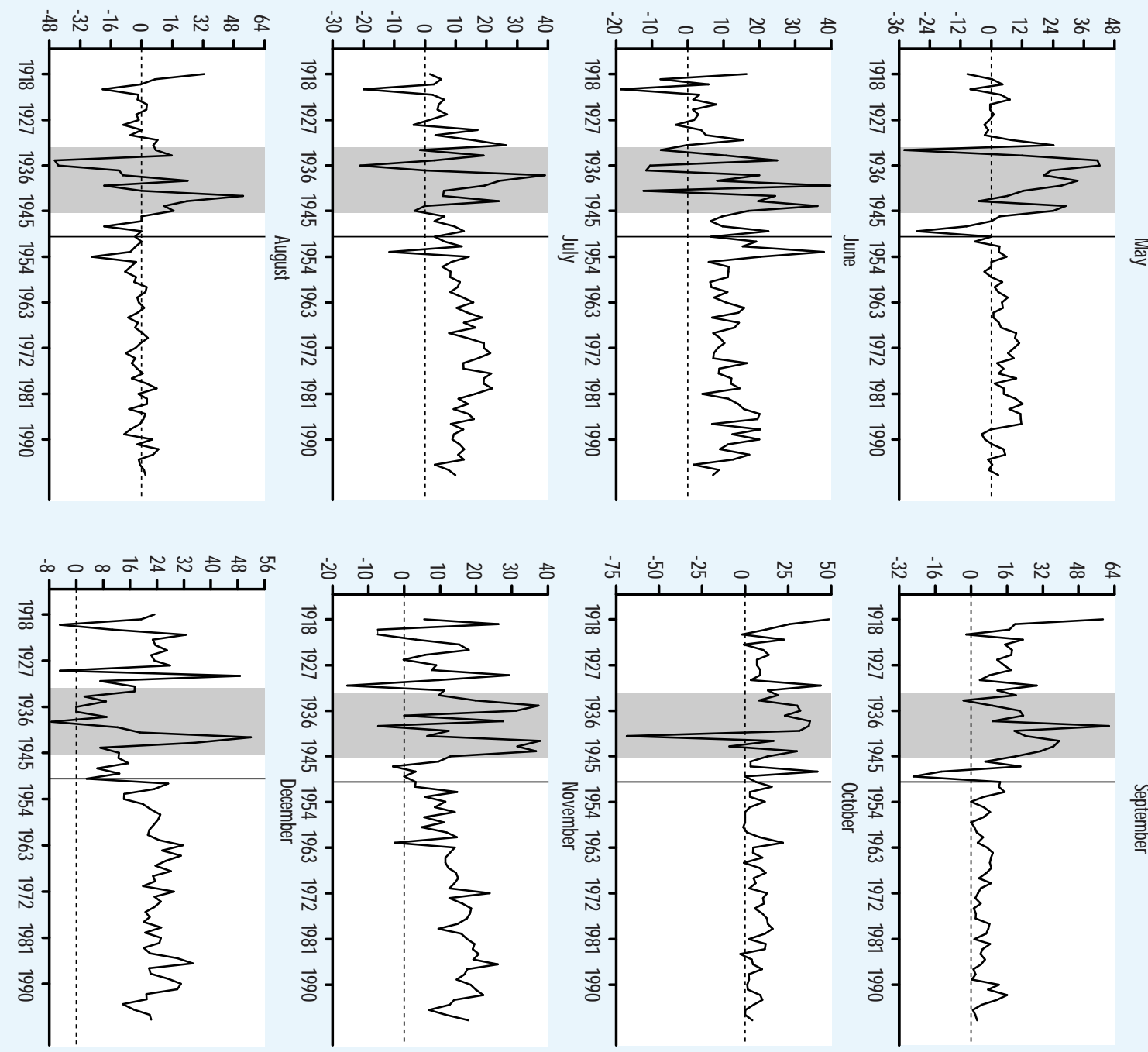
average filters that eventually are- after all steps are completed and if series length permits-approximately 12 years wide. $\mathrm{N}$ earer to the ends of the sample, the filters are truncated by folding the weights back onto the observed data. If there are structural breaks in the data generating process, such seasonal adjustment factors may be affected for a significant number of periods before the break.

The X12-regARIM A package consists of two parts. The first fits seasonal BoxJenkins $(p, d, q) \times(P, D, Q)$ ARIMA models to the data series, with intervention terms as suggested by Box and Tiao (1975). These are regression models with ARIMA error processes, or regARIMA models. The X12-regARIMA program can generate several types of intervention variables: additive outliers, or single anomalous observations; level shifts, or permanent shifts in the series; temporary changes, where the level of the series is unusually high or low but decays for several periods back to its previous regime; and ramps, where the level may take several periods to move up or down permanently. After a sequence of general-to-specific tests, the accepted dummy variables are included as intervention terms in a dynamic regression model with a seasonal ARIMA disturbance. Forecasts from the regARIMA model also are appended to the series. N ext, the X11 algorithm is used to obtain seasonal adjustment factors.

For messy data, there is some evidence that the X12 ARIMA-model pre-filtering may provide superior estimates of the seasonal adjustment factors. In our view, a recommendation by the $X 12$ algorithm that a large number of intervention terms should be added to the ARIM A model also suggests that an unusual shock (or sequence of shocks) has disrupted the regular seasonal pattern of economic activity. If so, it perhaps is unwise to allow the $\mathrm{X} 11$ or $\mathrm{X} 12$ programs to replace a large number of observations because a subsequent $X 11$ estimation might appear to find stable seasonal patterns when they are, in fact, not present.

Figure 5 shows growth rates and X11estimated seasonal factors for various periods beginning with January 1918 and ending with December for the years 1929,
1932, 1933, and 1934. (Data shown in the figure include seasonal factors that are forecast by the X 11 program for dates after the end of sample used for estimation.) Our previous analysis suggested a possible break in the data generating process circa 1932. This is confirmed by the estimates: Even with replacement of extreme observations, the seasonal adjustment factors for most months between 1928 and 1932 are strongly affected by the inclusion of data for 1933 and 1934. When estimating the period between 1918 and 1932, the X11 al gorithm replaced most observations for the months of July through December between 1918 and 1920, as well January and February 1921; October 1921 through February 1922; December 1929 through February 1930; and October through December 1930. Historical events suggest that these replacements may be reasonable. The years between 1918 and 1921 were turbulent, with substantial gold flows associated with the war and its aftermath. The period between October and December 1930 includes the first banking crisis during the 1930s.

Results obtained from the $X 12$ program are shown in Figure 6 . Based on a seasonal $(1,1,1) \times(0,1,1)$ ARIMA model, the X12 algorithms suggested eight outliers, marked by vertical lines and labeled by type in Figure 6 . Perhaps most prominent are the intervention variables in October 1931 when Britain left the gold standard and bank runs in the United States surged; in March 1933 the month of the U.S. "Bank Holiday;" and in early 1934, when the Federal Reserve sharply curtailed growth of Federal Reserve credit. We used the $X 11$ algorithm within the X12-regARIM A package to calculate seasonal adjustment factors after accounting for these interventions. For four sample periods- each beginning in January 1918 and ending, respectively, in December of $1929,1932,1933$, and 1934-the factors resembled those obtained from conventional $\mathrm{X} 11$ estimation, and hence, are not shown.

Seasonal variation between 1933 and 1949 is examined in detail in Figures 7 and 8. Our previous statistical results, based on deterministic seasonal effects, suggested that life simply was not the same during 

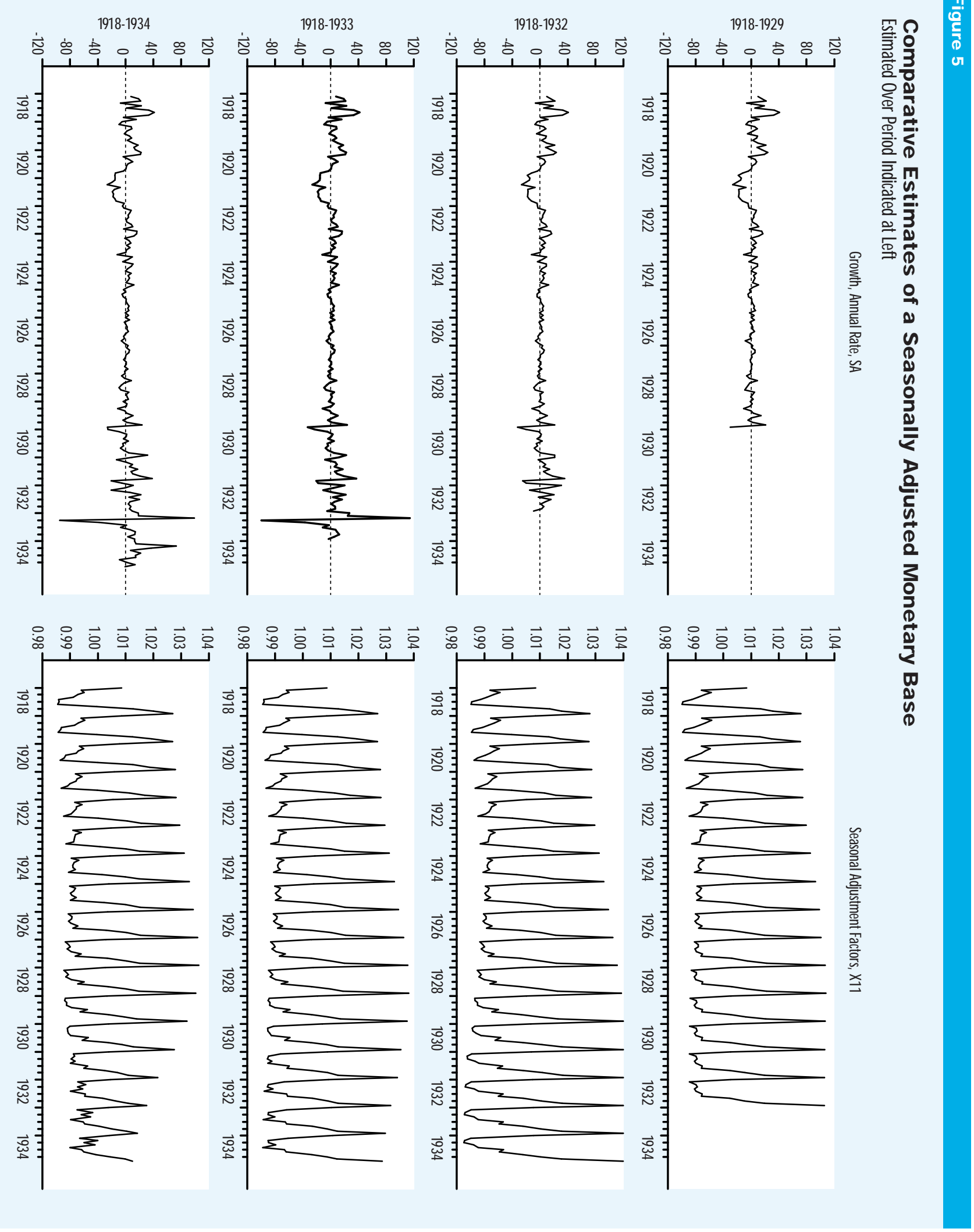


\section{Figure 6}

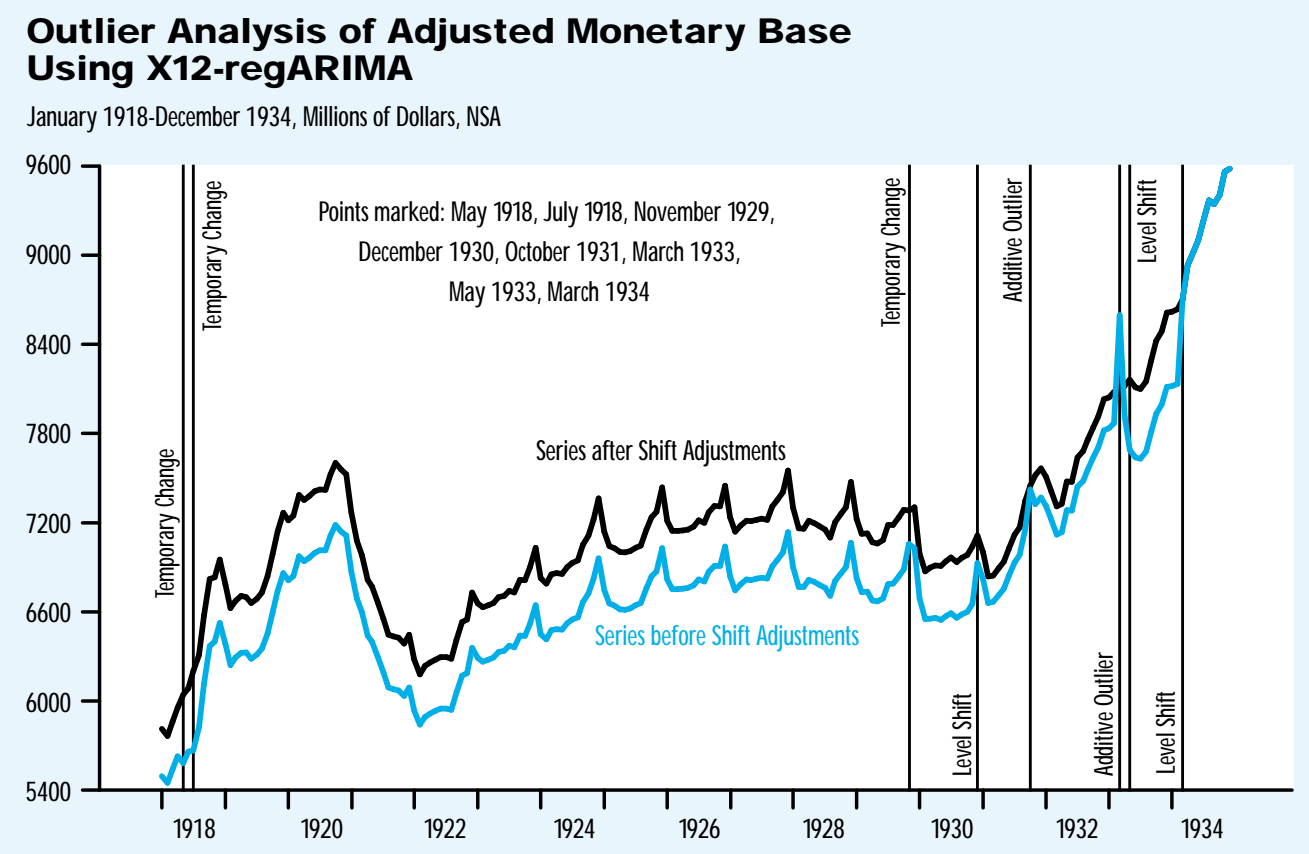

these decades. This, of course, is easy to rationalize: Extraordinary economic events such as the Great Depression and World War II likely interrupted previous seasonal patterns. During the Depression, many families had insufficient income to support their usual summer travel and holiday buying habits. During the war, despite adequate income, many consumer goods were either in short supply or rationed. The weakness of the seasonality is evident in both the growth rates and autocorrelation function of the seasonally unadjusted data shown in Figure 7. Nevertheless, the data do display some seasonality, with small spikes in the autocorrelation function for seasonally unadjusted data at lags of 6,12 , and 24 months. Both the $X 11$ and $X 12$ packages return factors that annihilate the 12-month seasonal correlation. Yet, these patterns are distinctly different between decades, which suggests that the estimates are imprecise.

Further results for the period between 1933 and 1949, based on the X12 program, are shown in Figure 8 . For data between January 1918 and December 1949, the program's regARIMA outlier identification al gorithms suggest 25 intervention terms to handle outliers; the dates associated with these terms are marked with vertical lines in Figure 8. The months marked in the figure are N ovember 1929; December 1930; O ctober 1931; M arch and May 1933; March 1934; February 1935; February, May, and August 1936; February and April 1937; March and July 1938; A pril, September, November, and December 1939; August 1940; October 1941; August 1942; October 1943; October 1948; and, April and September, 1949. N ote that each of these intervention variables may affect observations for more than one month, as is evident in Figure 6.

In our judgment, based on estimates from both the X 11 and X12-regARIMA programs, seasonal variation between 1933 and 1949 was more than likely altered sharply by extraordinary economic events. Any residual seasonality is both too uncertain and unstable to allow usable estimates of seasonal adjustment factors. Hence, we include these years in our final series without seasonal adjustment.

Estimated seasonal adjustment factors for the last five decades of our data, between 

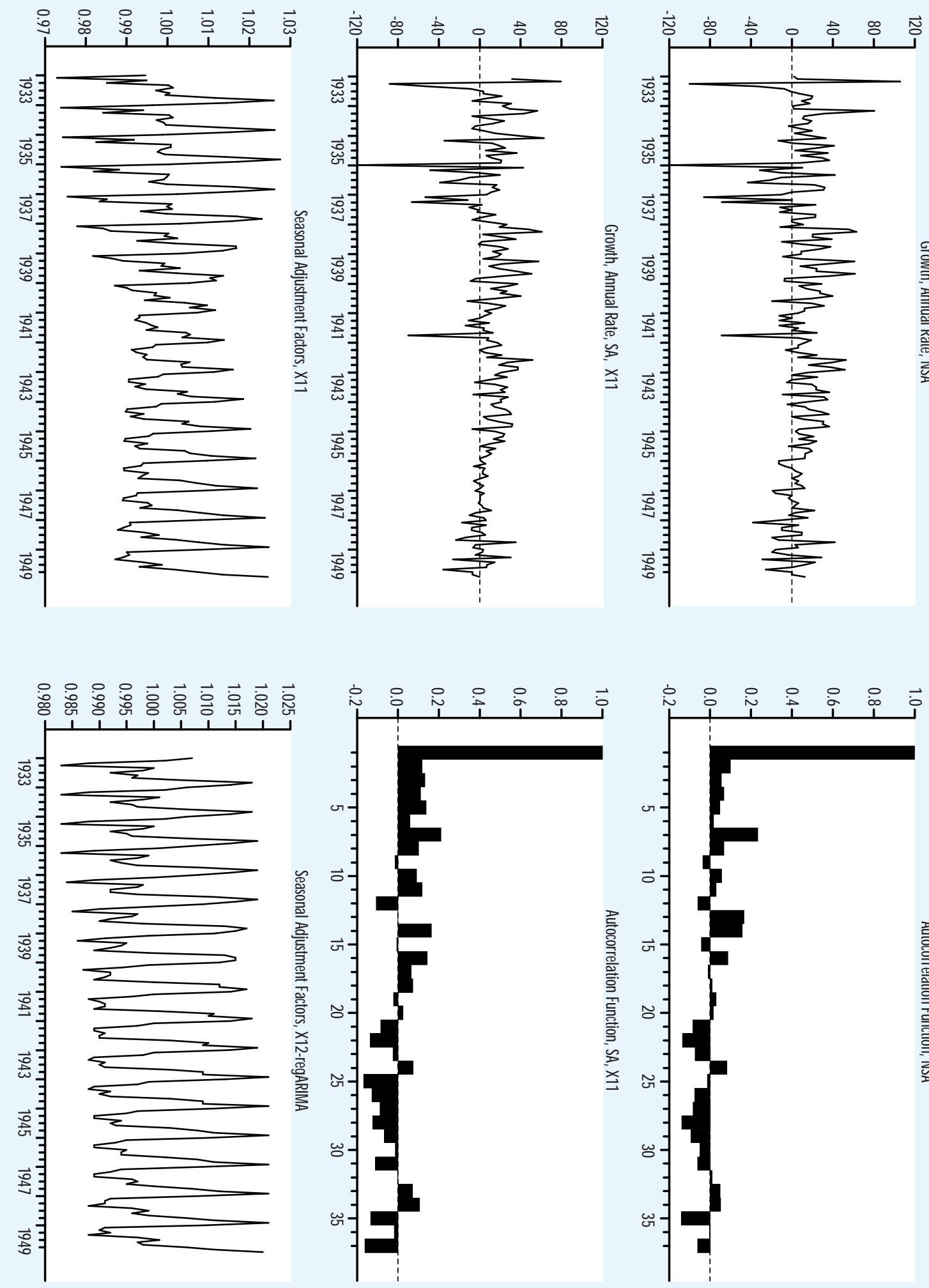


\section{Figure 8}

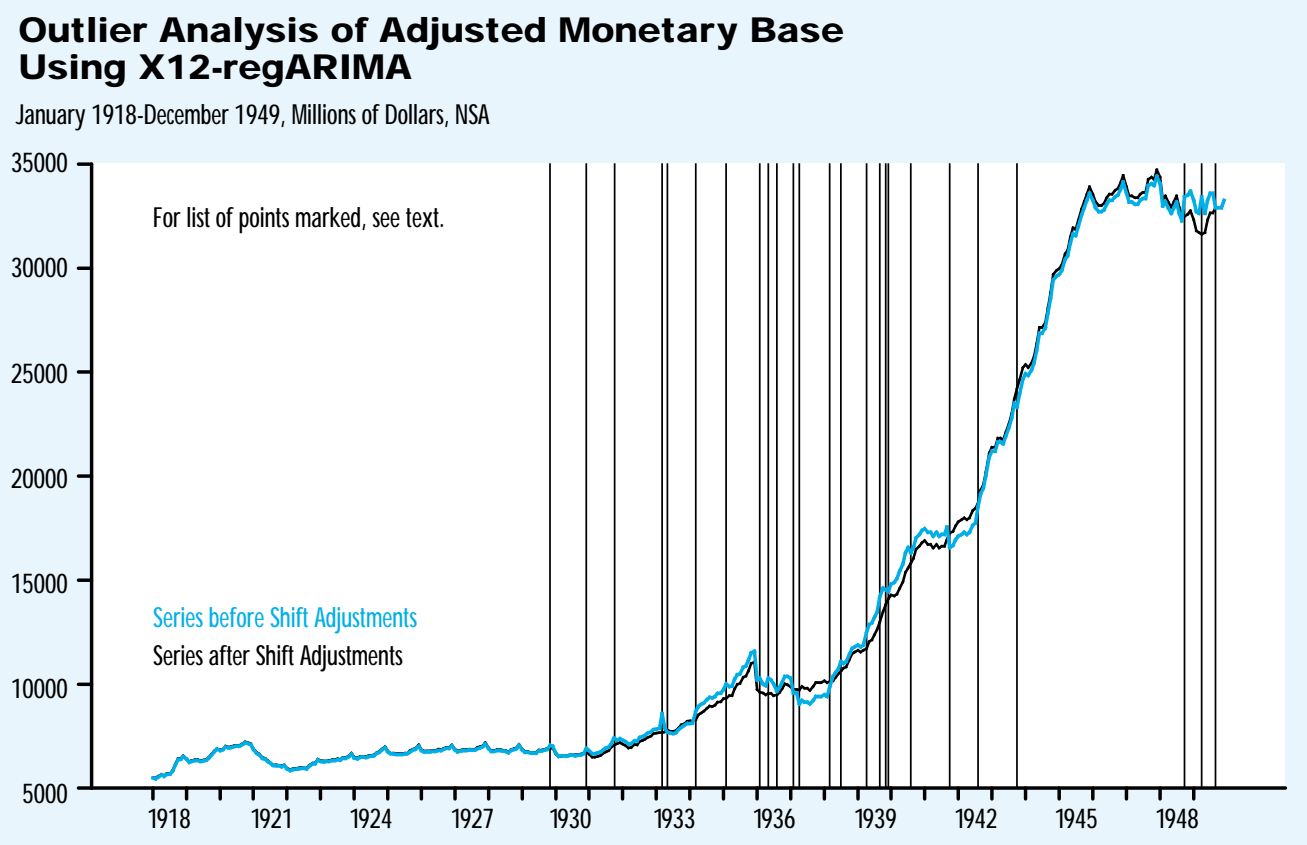

1950 and 1997, are shown in Figure 9. Growth rates also are shown for both the seasonally adjusted and unadjusted data. As our earlier statistical tests suggest, seasonal patterns during this period are relatively steady. Seasonal adjustment factors from both the X 11 and $X 12$ programs display some time variation but, except for a diminution during the 1990s, are relatively stable. The X12-regARIMA outlier analysis suggests interventions in December 1950, January 1951, June 1953, August 1954, February 1958, October 1962, April 1980, and January 1981. The diminution during the 1990s likely reflects the increasing amount of U.S. currency held outside the United States (Anderson and Rasche, 1998).

\section{SUMMARY AND CONCLUSIONS}

This study has extended the adjusted monetary base published by the Federal Reserve Bank of St. Louis to include the period between 1918 and 1935. It seems unlikely that this measure of the monetary base can be pushed any earlier, due to a scarcity of data and the major changes in the structure of reserve requirements that were implemented in 1917. Month-average data necessary to measure the monetary base, for example, begin August 1917 (see the shaded insert "Why Does RAM Begin in 1917?"). Readers are cautioned that attempts to splice our data to other series (such as Friedman and Schwartz's) must somehow adjust for the differences between dailyaverage and end-of-period data.

Our previous research has provided data on the adjusted monetary base beginning January 1936. In this analysis, we have introduced an additional RAM adjustment, RAM (1922), to measure the effects of changes in statutory reserve requirements between 1917 and 1935. We chained our previously estimated adjusted monetary base to these new data in August 1935, providing a consistently measured 80 years of the adjusted monetary base for the United States.

An examination of the seasonal properties of the adjusted monetary base suggests that estimates of stable seasonal 


\section{REVIEW}

JANUARY / FEBRUARY 1999

\section{Figure 9}

Seasonal Adjustment, 1950-1997
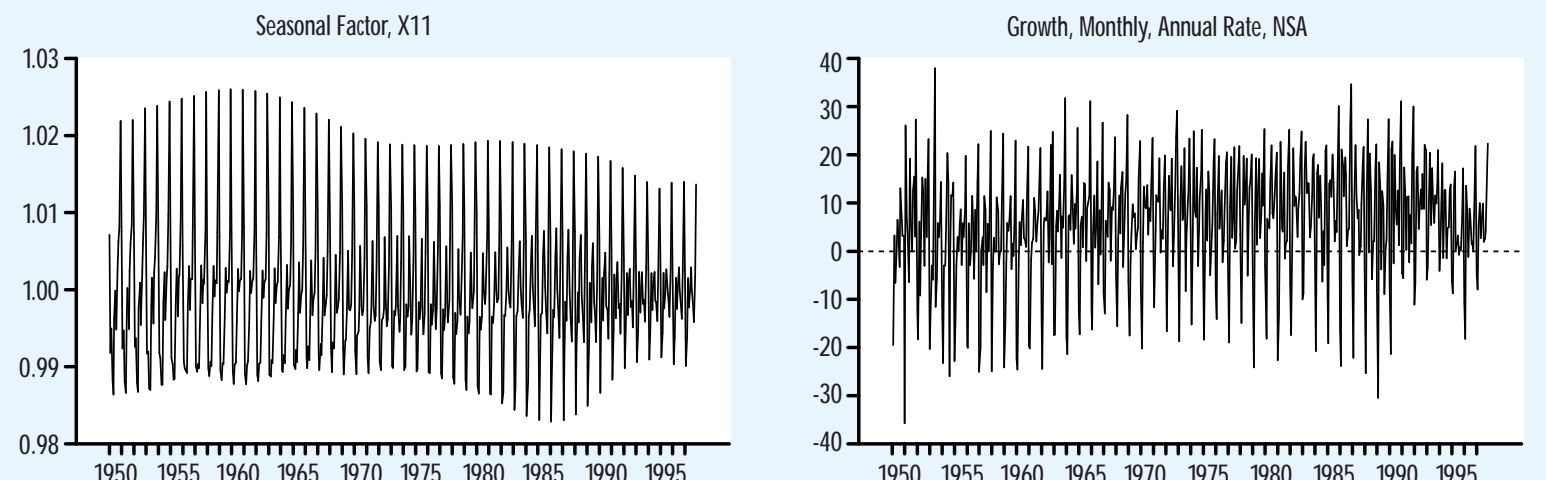

Seasonal Factor, X12-regARIMA
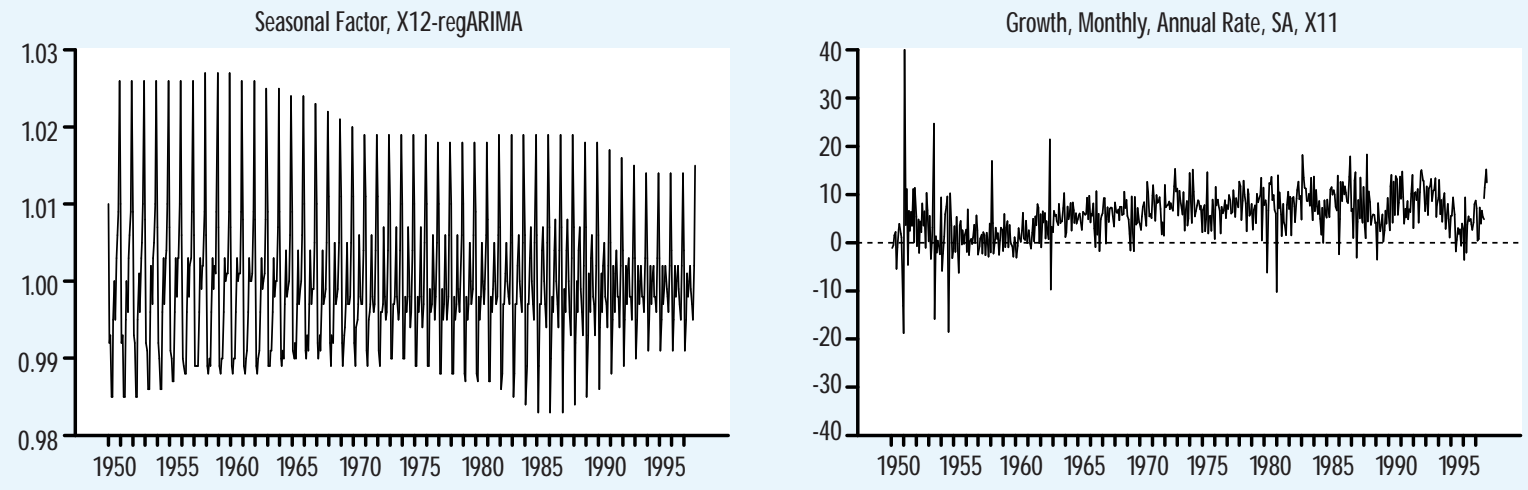

factors are readily obtained between 1918 and 1932 and between 1950 and 1997. But, our analysis suggests that seasonal variation in the adjusted monetary base nearly vanished during the Great Depression and World War II: These were not years of business as usual for the economy. We include those data in our final series on a seasonally unadjusted basis, to avoid inducing spurious seasonal patterns in the final seasonally adjusted data.

\section{REFERENCES}

Andersen, Leonall C., and Jerry L. Jordan. "The Monetary BaseExplanation and Analytical Use," this Review (August 1968), pp. 7-11. Anderson, Richard G., and Robert H. Rasche. "A Revised Measure of the St. Louis Adjusted Monetary Base," this Review (March/ April 1996) (1996a), pp. 3-13.

and _._. "Measuring the Adjusted Monetary Base in an Era of Financial Change," this Review (November/ December 1996) (1996b), pp. 3-37. and "The Domestic Adjusted Monetary Base," mimeo, Federal Reserve Bank of St. Louis (July 1998).

Balbach, Anatol B., and Albert E. Burger. "Derivation of the Monetary Base," this Review (November 1976), pp. 2-8.

Barsky, Robert B., and Jeffrey A. Miron. "The Seasonal Cycle and the Business Cycle," Journal of Political Economy (June 1989), pp. 503-34.

Beaulieu, J. Joseph, Jeffrey K. MacKie-Mason, and Jeffrey A. Miron. "Why Do Countries and Industries with Large Seasonal Cycles Also Have Large Business Cycles," Quarterly Joumal of Economics (May 1992), pp. 621-56.

Board of Governors of the Federal Reserve System. Banking and Monetary Statistics 1914- 1941 (November 1943).

. Twenty-Second Annual Report of the Board of Governors of the Federal Reserve System, Covering Operations for the Year 1935 (May 1936).

Twenty-Third Annual Report of the Board of Governors of the Federal Reserve System, Covering Operations for the Year 1936 (J une 1937).

Fifty-Ninth Annual Report of the Board of Govemors of the Federal Reserve System, 1972 (May 1973). 
Federal Reserve Bulletin, various issues.

Box, George, and George C. Tiao. "Intervention Analysis with Applications to Economic and Environmental Problems," Journal of the American Statistical Association (March 1975), pp. 70-79.

Brunner, Karl, and Allan H. Meltzer. "The Federal Reserve's Attachment to the Free Reserve Concept," Originally presented to the U.S. Subcommittee on Domestic Finance on May 7, 1964. Reprinted in Monetary Economics, Karl Brunner and Allan H. Meltzer, eds., Basil Blackwell (1989), pp. 21-96.

Burger, Albert $E_{\text {., }}$ and Robert H. Rasche. "Revision of the Monetary Base," this Review (July 1977), pp. 13- 28.

den Butter, F.A.G., and M.M.G. Fase. Seasonal Adjustment as a Practical Problem, North Holland (1991).

Deutsche Bundesbank. "Review of the monetary target and restructuring of the minimum reserve regulations," Monthly Report (July 1995), pp. 17-35.

Findley, David F., Brian C. Monsell, William R. Bell, Mark C. Otto, and Bor-Chung Chen. "New Capabilities and Methods of the X-12-ARIMA Seasonal Adjustment Program," Journal of Business and Economic Statistics (April 1998), pp. 127-52.

Friedman, Benjamin M. "Targets and Instruments of Monetary Policy," Handbook of Monetary Economics, vol. 2, Benjamin M. Friedman and Frank H. Hahn, eds., Elsevier Science Publishers (1990), pp. 1186-230.

Friedman, Milton, and Anna J. Schwartz. A Monetary History of the United States, 1867-1960, Princeton University Press (1963).

Harvey, Andrew, and Andrew Scott. "Seasonality in Dynamic Regression Models," Economic Journal (November 1994), pp. 1324- 45.

McCallum, Bennett T. "Issues in the Design of Monetary Policy Rules," NBER Working Paper No. 6016 (April 1997).

_ _ _ "Some Issues Conceming Interest Rate Pegging, Price Level Determinancy and the Real Bills Doctrine," Journal of Monetary Economics (January 1986), pp. 135-60.

McCallum, Bennett $T_{1}$, and Monica Hargraves. "A Monetary Impulse Measure for Medium-Term Policy Analysis," Staff Studies for the World Economic Outlook, International Monetary Fund (September 1995), pp. $52-70$.

Moody's. Bank Directory 1928 (1928).

Patinkin, Don. "Financial Intermediaries and the Logical Structure of Monetary Theory: A Review Article," American Economic Review (March 1961), pp. 95-116.
Poole, William. "Optimal Choice of Monetary Policy Instruments in a Simple Stochastic Macro Model," Quarterly J oumal of Economics (May 1970), pp. 197-216.

Rand McNally and C0., Bank Directory 1919 (1919).

Tatom, John. "Issues in Measuring An Adjusted Monetary Base," this Review (December 1980), pp. 11-29.

Wallis, Kenneth. "Seasonal Adjustment and Relations Between Variables," Joumal of the American Statistical Association (March 1974), pp. 18-31. 